\title{
Tingkat Kepatuhan Wajib Pajak Badan Usaha Mikro Kecil dan Menengah Setelah Diberlakukan Tarif $1 \%$ (Final) PPh (Studi Kasus di KPP Pratama Pontianak)
}

\author{
Sari Zawitri* \\ Politeknik Negeri Pontianak \\ Elsa Sari Yuliana \\ Politeknik Negeri Pontianak
}

\begin{abstract}
Year 2015 is the year for developing Tax Payer and the year of issuance of Government Regulation No. 46 Year 2013, which imposed 1\% tax to SMEs with a turnover (gross income) from Rp 1 to a maximum of Rp 4.8 billion per year. The research problems are formulated: (1) How does the level of tax compliance in KPP Pratama Pontianak before and after the $1 \%$ tax policies for SME corporate tax payer? (2) What efforts made by the tax authorities in improving tax payer compliance company in terms of delivering the tax obligations on KPP Pratama Pontianak. The research method was an exploratory, descriptive, narrative case study approach to the object KPP Pratama Pontianak. Outcomes of this study are expected KPP Pratama Pontianak be an example or reference for other KPP in performing their duties and functions as public service on tax. The results showed that there was a slight increase tax payer compliance in KPP Pontianak after their policy of $1 \%$ per month tax on turnover (gross income), when compared with the prior policy. Suggestions for the government, in this case the Directorate General of Taxation, in formulating tax policy in order to maximize tax revenue.
\end{abstract}

Keywords : Government regulation no 46 2013, Compliance taxpayers, The letter of the tax, The letter of annual tax.

\section{PENDAHULUAN}

Sumber penerimaan negara terbesar berasal dari pajak, maka pemerintah harus melakukan peningkatan realisasi penerimaan pajak. Potensi pajak di Indonesia yang dapat dipungut dari masyarakat masih memiliki peluang yang sangat besar. Direktorat Jendral Pajak memperkirakan dari target penerimaan pajak yang ditetapkan sesuai APBN-P 2015 sebesar Rp 1.294,258 triliun, realisasi penerimaan pajak hanya mencapai

\footnotetext{
* Korespondensi: Sari Zawitri, Jurusan Akuntansi, Politeknik Negeri Pontianak, Jalan A. Yani, Pontianak 78124, Indonesia. Alamat Email: zawiakpolnep@gmail.com.
} 
15,32\% (Direktorat Jenderal Pajak, 2015). Maka masih perlu dilakukan maksimalisasi kepatuhan wajib pajak dalam memenuhi kewajiban pajaknya.

Tahun 2015 merupakan Tahun Pembinaan Wajib Pajak, yaitu merupakan salah satu kebijakan perpajakan yang sangat diharapkan dapat meningkatkan penerimaan pajak. Melalui kebijakan ini, wajib pajak dihimbau agar membetulkan SPT Tahunannya hingga 5 tahun terakhir atas kemauan sendiri, dengan insentif pembebasan sanksi administrasi. Berkaitan dengan keberhasilan kebijakan perpajakan oleh Direktorat Jenderal Pajak, tidak terlepas dengan sistem pemungutan pajak yang berlaku di Indonesia yaitu self assessment system. Sistem self assessment membuka peluang dilakukannya kecurangan-kecurangan oleh para wajib pajak dalam memenuhi kewajiban perpajakannya. Karena sistem self assessment tersebut membutuhkan kepatuhan sukarela dari Wajib Pajak yang diwujudkan jika terpenuhinya unsur kesadaran perpajakan dan unsur tindakan penegakan hukum.

Penetapan Peraturan Pemerintah Nomor 46 Tahun 2013 memberlakukan pajak $1 \%$ untuk pengusaha UKM dengan omset (peredaran bruto) mulai 1 hingga maksimal hingga $\mathrm{Rp}$ 4,8 miliar per tahun. Nantinya pajak akan dipungut 1\% (satu persen) tiap bulan berdasarkan omset penjualan di bulan itu. Aturan pajak penghasilan sebesar 1 persen omset untuk mendorong UKM agar mulai membuat pembukuan usaha secara tertib dengan membuat faktur penjualan dan bukti kuitansi pengeluaran, agar pajak yang dibayar sesuai laba usaha yang sebenarnya. Dimana kontribusi Usaha Mikro Kecil Menengah (UMKM) sebesar 57,48\% terhadap PDB dan juga proporsi UMKM sebesar 99,99\% (Kemenkop, 2013) dari jumlah pelaku usaha menunjukkan eksistensi UMKM dalam menunjang perekonomian negara Indonesia. Dan Pontianak merupakan salah satu kota dengan potensi UMKM kedua terbesar di kawasan Kalimantan setelah Balikpapan. Kota Pontianak memiliki beberapa UMKM yang bergerak di bidang kerajinan dan makanan. UMKM di kota Pontianak memiliki omset rata-rata di bawah 4,8 miliar/tahun dengan tarif kewajiban pajak $1 \%$ perbulan dari omset.

Masalah dalam penelitian ini dirumuskan sebagaimana tujuannya adalah sebagai berikut. Pertama, bagaimana tingkat kepatuhan wajib pajak badan di KPP Pratama Pontianak sebelum dan sesudah adanya kebijakan pajak $1 \%$ untuk pengusaha UMKM dengan omset (peredaran bruto) mulai 1 hingga maksimal hingga Rp 4,8 miliar per tahun bagi Wajib Pajak badan UMKM? Kedua, apa upaya-upaya yang dilakukan fiskus dalam meningkatkan kepatuhan Wajib Pajak badan dalam hal menyampaikan kewajiban perpajakannya di KPP Pratama Pontianak?

Masalah dibatasi dengan: (1) Menghitung dan menyetor kewajiban pajak $1 \%$ dari omset perbulan wajib pajak, dan (2) Melapor (Surat Pemberitahuan) SPT Tahunan Badan yang bersifat final sebesar $1 \%$ dari omset setiap bulan tepat pada waktunya. Manfaat yang diharapkan dari penelitian ini adalah: (1) Bagi UMKM, diharapkan dapat memberikan sumbangan pemikiran tentang penerapan Peraturan Pemerintah Nomor 46 Tahun 2013 dan memenuhi kewajiban perpajakan sebagai bentuk pertanggungjawaban 
pelaku bisnis di negara Indonesia. (2) Penelitian memberikan masukan bagi Direktorat Jenderal Pajak dalam merumuskan kebijakan perpajakan bagi sektor UMKM untuk meningkatkan kepatuhan wajib pajaknya dan bagi pihak KPP Pontianak agar dapat lebih memaksimalkan penerimaan pajak. (3) Penelitian ini diharapkan menjadikan KKP Pratama Pontianak menjadi contoh atau referensi bagi KKP lainnya dalam menjalankan tugas dan fungsi sebagai pelayanan kewajiban pajak masyarakat Pontianak.

\section{TINJAUAN PUSTAKA}

\subsection{Definisi Pajak}

Membahas mengenai perpajakan tidak terlepas dari pengertian pajak itu sendiri. Menurut Prof. Dr. Rochmat Soemitro, SH yang dikutip dalam buku Mardiasmo (2011) "Pajak adalah iuran rakyat kepada kas Negara berdasarkan Undang-undang (yang dapat dipaksakan) dengan tiada mendapat jasa timbal (kontra Prestasi) yang langsung dapat ditunjukkan dan yang digunakan untuk membayar pengeluaran umum". Sedangkan menurut P. J. A. Andriani yang dikutip oleh Waluyo (2013), "Pajak adalah iuran masyarakat kepada Negara (yang dipaksakan) yang terutang oleh yang wajib membayarnya menurut peraturan-peraturan umum (undang-undang) dengan tidak mendapat prestasi kembali yang langsung dapat ditunjuk dan yang gunanya adalah untuk membiayai pengeluaran-pengeluaran umum berhubung tugas Negara untuk menyelenggarakan pemerintahan".

Dari kedua definisi tersebut di atas memiliki persamaan prinsip mengenai pajak. Perbedaannya hanya pada penggunaan gaya bahasa atau kalimatnya saja. Kedua pendapat tersebut mempunyai kesamaan unsur-unsur, seperti pajak dipungut berdasarkan Undang-Undang, tidak ada timbal jasa (Kontraprestasi) secara langsung, dapat dipaksakan dan hasilnya digunakan untuk membiayai pembangunan. Maka, dapat disimpulkan bahwa pajak adalah iuran kepada Negara (yang dapat dipaksakan) yang terutang oleh yang wajib membayarnya menurut peraturan-peraturan dan tidak mendapatkan prestasi-prestasi kembali yang secara langsung dapat ditunjuk.

\subsection{Definisi Wajib Pajak dan Definisi Pajak Penghasilan}

Undang-undang Nomor 28 Tahun 2007 Pasal 1 ayat 2 mendefinisikan Wajib Pajak adalah Orang Pribadi atau Badan,meliputi pembayar pajak, pemotong pajak, dan pemungut pajak yang mempunyai hak dan kewajiban perpajakan sesuai dengan ketentuan Peraturan Perundang-undangan perpajakan. Orang Pribadi merupakan Subjek Pajak yang bertempat tinggal atau berada di Indonesia ataupun di luar Indonesia. Menurut Undang-undang Nomor 28 Tahun 2007 (2007:3), Ketentuan Umum dan Tata Cara Perpajakan menyebutkan bahwa: 
Badan adalah sekumpulan orang atau modal yang merupakan kesatuan, baik yang melakukan usaha maupun yang tidak melakukan usaha yang meliputi perseroan terbatas, perseroan komanditer, perseroan lainnya, Badan Usaha Milik Negara atau Badan Usaha Milik Daerah dengan nama dan dalam bentuk apapun, firma, kongsi koperasi, dana pensiun, persekutuan, perkumpulan, yayasan, organisasi massa, organisasi sosial politik, atau organisasi lainnya, lembaga dan bentuk badan lainnya termasuk kontrak investasi kolektif dan bentuk usaha tetap.

Untuk pajak penghasilan, Soebakir, dkk (1996) mengemukakan definisi:

Pajak penghasilan sebagai suatu pajak yang dikenakan terhadap subjek pajak atas penghasilan yang diterima atau diperolehnya dalam tahun pajak. Salah satu subjek pajak adalah badan, terdiri dari perseroan terbatas, Perseroan Komanditer, Perseroan Lainnya, Badan Usaha Milik Negara, Badan Usaha Milik Daerah dengan nama dan dalam bentuk apapun, persekutuan, perkumpulan, firma, kongsi, koperasi, yayasan atau organisasi yang sejenis, lembaga dana pensiun dan bentuk badan usaha lainnya. Dengan demikian, pajak penghasilan badan yang dikenalkan terhadap salah satu bentuk usaha tersebut, atas penghasilan yang diterima atau diperolehnya dalam satu tahun pajak.

\subsection{Pajak Penghasilan Badan PP 46/2013 - PPh final untuk WP dengan Omset di bawah Rp. 4,8 Miliar Per Tahun}

PP 46/2013 join Peraturan Menteri Keuangan 107/011/2013 mulai berlaku pada tanggal 1 Juli 2013. Tarifnya 1\% dari DPP jumlah peredaran bruto setiap bulan untuk setiap tempat kegiatan usaha (KPP tiap-tiap cabang). Peraturan ini berlaku untuk perusahaan yang omset tahun 2012 kurang dari Rp. 4,8 Miliar. Sehingga bila omset setahun lebih dari Rp. 4,8 Miliar tidak perlu menyetor PPh final ini. Subjek Pajak tidak termasuk Bentuk Usaha Tetap (BUT) dan yang berpenghasilan dari pekerjaan bebas seperti wajib pajak orang pribadi notaris, konsultan hukum, dan lain-lain. Objek pajak tidak termasuk penghasilan yang sudah dikenakan $\mathrm{PPh}$ final dari pajak penghasilan lainnya seperti jasa konstruksi, sewa tanah/bangunan, dan lain-lain.

Menurut PMK 107/2013, Wajib Pajak yang hanya menerima atau memperoleh penghasilan yang dikenai Pajak Penghasilan yang bersifat final (PP 46/2013), tidak diwajibkan melakukan pembayaran angsuran pajak sebagaimana dimaksud dalam Pasal 25 Undang-Undang Pajak Penghasilan dan Pembebasan dari pemotongan dan/atau pemungutan Pajak Penghasilan oleh pihak lain melalui Surat Keterangan Bebas yang diterbitkan oleh Kepala Kantor Pelayanan Pajak tempat Wajib Pajak terdaftar atas nama Direktur Jenderal Pajak berdasarkan permohonan Wajib Pajak. Ketentuan terkait perhitungan pajak tahunan sehubungan dengan penerapan PP 46 bisa dilihat pada SE42/PJ/2013 bagian F. Hal-Hal Khusus Terkait Pengenaan Pajak Penghasilan yang bersifat final pada poin 11 sebagai berikut: 
a. Peredaran usaha dihitung berdasarkan seluruh peredaran usaha selama Tahun Pajak 2013, tidak termasuk peredaran usaha pada Masa Pajak Juli 2013 sampai dengan Desember 2013 yang dikenai Pajak Penghasilan Pasal 4 ayat (2);

b. Bagi Wajib Pajak orang pribadi, untuk menentukan Penghasilan Kena Pajak dikurangi terlebih dahulu dengan Penghasilan Tidak Kena Pajak setahun;

c. Angsuran Pajak Penghasilan Pasal 25 Undang-Undang Pajak Penghasilan Masa Pajak Januari 2013 sampai dengan Juni 2013 dikreditkan terhadap Pajak Penghasilan yang terutang untuk Tahun Pajak yang bersangkutan.

\subsection{Kepatuhan Wajib Pajak}

Kondisi perpajakan yang menuntut keikutsertaan aktif wajib pajak dalam menyelenggarakan perpajakannya membutuhkan kepatuhan wajib pajak yang tinggi, yaitu kepatuhan dalam pemenuhankewajiban perpajakan yang sesuai dengan kebenarannya. Kepatuhan memenuhi kewajiban perpajakan secara sukarela (voluntary of complience) merupakan tulang punggung dari self assesment system, dimana wajib pajak bertanggung jawab menetapkan sendiri kewajiban perpajakan kemudian secara akurat dan tepat waktu dalammembayar dan melaporkan pajaknya. Pengertian kepatuhan Wajib Pajak menurut Safri Nurmantu yang dikutip oleh Rahayu (2010), menyatakan bahwa "Kepatuhan perpajakan dapat didefinisikan sebagai suatu keadaan dimana Wajib Pajak memenuhi semua kewajiban perpajakan dan melaksanakan hak perpajakannya". Sedangkan, pengertian kepatuhan Wajib Pajak menurut Chaizi Nasucha yang dikutip oleh Rahayu (2010), menyatakan bahwa kepatuhan Wajib Pajak dapat didefinisikan dari sebagai "kewajiban Wajib Pajak dalam mendaftarkan diri, kepatuhan untuk menyetorkan kembali Surat pemberitahuan, kepatuhan dalam perhitungan dan pembayaran pajak terutang, kepatuhan dalam pembayaran tunggakan". Selain itu, menurut Keputusan Menteri Keuangan No.544/KMK.04/2000, kepatuhan perpajakan diartikan sebagai "tindakan Wajib Pajak dalam pemenuhan kewajiban perpajakannya sesuai dengan ketentuan peraturan perundang-undangan dan peraturan pelaksanaan perpajakan yang berlaku dalam suatu negara"

Adapun jenis-jenis kepatuhan Wajib Pajak menurut Devano dan Rahayu (2006:110) adalah:

a. Kepatuhan formal adalah suatu keadaan dimana wajib pajak memenuhi kewajiban secara formal sesuai dengan ketentuan dalam Undang-undang perpajakan

b. Kepatuhan material adalah suatu keadaan dimana wajib pajak secara substantif/hakikatnya memenuhi semua ketentuan material perpajakan yaitu sesuai isi dan jiwa Undang-undang pajak kepatuhan material juga dapat meliputi kepatuhan formal. Misalnya ketentuan batas waktu penyampaian Surat Pemberitahuan Pajak Penghasilan (SPT PPh) Tahunan tanggal 31 Maret. 
Apabila wajib pajak telah melaporkan Surat Pemberitahuan Pajak Penghasilan Tahunan sebelum atau pada tanggal 31 Maret maka wajib pajak telah memenuhi ketentuan formal, akan tetapi isinya belum tentu memenuhi ketentuan material, yaitu suatu keadaan dimana Wajib Pajak secara subtantive memenuhi semua ketentuan material perpajakan, yakni sesuai isi dan jiwa undang-undang perpajakan. Kepatuhan material dapat meliputi kepatuhan formal. Wajib Pajak yang memenuhi kepatuhan material adalah Wajib Pajak yang mengisi dengan jujur, lengkap dan benar Surat Pemberitahuan (SPT) sesuai ketentuan dan menyampaikannya ke KPP sebelum batas waktu berakhir.

Evaluasi tingkat kepatuhan Wajib Pajak Badan adalah menilai tingkat ketaatan sekumpulan orang dan atau modal yang menurut ketentuan perundang-undangan perpajakan ditentukan untuk melakukan kewajiban perpajakan, termasuk pemungut pajakatau pemotong pajak tertentu, yang merupakan kesatuan baik melakukan usaha maupun tidak melakukan usaha yang meliputi Perseroan Terbatas, Perseroan Komanditer, perseroan lainnya, Badan Usaha Milik Negara atau Daerah dengan nama dan dalam bentuk apapun, firma, kongsi, koperasi, dana pensiun, persekutuan, perkumpulan, yayasan, organisasi massa, organisasi social politik atau organisasi yang sejenis, lembaga, bentuk usaha tetap dan bentuk badan lainnya.

\section{METODE PENELITIAN}

Penelitian ini adalah penelitian dengan jenis riset eksploratoria yang bersifat deskriptif naratif. Penelitian eksploratoria adalah suatu penelitian yang dilakukan untuk memperoleh keterangan, penjelasan, dan data mengenai hal-hal yang belum diketahui. Penelitian ini berbentuk studi kasus, dalam bentuk Kantor Pelayanan Pajak Pratama Pontianak. Pemilihan Kantor Pelayanan Pajak Pratama Pontianak sebagai tempat penelitian, karena lokasinya berada di wilayah kerja peneliti.

Sedangkan data dikumpulkan dengan survei kuesioner, wawancara, dan studi literatur. Sumber data yang digunakan adalah data primer dan data sekunder. Dengan populasi seluruh wajib pajak badan yang masih aktif di KPP Pratama Pontianak. Dan sampel penelitian adalah bagian dari populasi yang diteliti, dengan teknik pengambilan sampel nonprobability sampling dengan purposive sampling. Sampel dalam penelitian sejumlah 100 responden, dengan menggunakan teori Slovin (Prasetyo, 2005) diambil secara acak (ditemui peneliti). Dari tabulasi jawaban responden dilakukan uji validitas dan realibilitas data. Teknik analisa dengan proses analisa data univariat, yaitu dengan menggunakan distribusi frekuensi dan persentase untuk mendeskripsikan satu variabel saja yaitu tingkat kepatuhan. 


\section{TEMUAN DAN PEMBAHASAN}

\subsection{Gambaran Umum Permasalahan}

Penetapan Peraturan Pemerintah Nomor 46 Tahun 2013 memberlakukan pajak $1 \%$ untuk pengusaha UMKM dengan omset (peredaran bruto) mulai 1 hingga maksimal hingga Rp 4,8 miliar per tahun. Pajak akan dipungut $1 \%$ (satu persen) tiap bulan berdasarkan omset penjualan di bulan itu. Aturan pajak penghasilan sebesar 1 persen omset untuk mendorong UMKM agar mulai membuat pembukuan usaha secara tertib dengan membuat faktur penjualan dan bukti kuitansi pengeluaran, agar pajak yang dibayar sesuai laba usaha yang sebenarnya. Agar pengeluaran ini tercatat di SPT (Surat Pemberitahuan) pajak, pelaku UMKM harus melakukan pembukuan, sehingga pajak yang dibayar sesuai dengan laba bersih. Terdapat tiga jenis kepatuhan wajib pajak badan yang harus dipenuhi oleh wajib pajak badan, yaitu kewajiban SPT Masa, kewajiban SPT Tahunan dan kewajiban lainnya.

Sehubungan dengan kewajiban SPT Masa, wajib pajak wajib menyetorkan pajak bulanan (masa) paling lambat tanggal 10 atau 15 bulan berikutnya setelah akhir masa pajak setiap bulannya ( $\mathrm{PPh} 21 / 26,23,4$ (2), 25). Dan untuk tahun pajak 2014-2015 (sesudah 1\%) setiap bulannya ditambah menyetor sebesar $1 \%$ dari peredaran bruto. Selain itu, wajib pajak wajib mengisi Surat Pemberitahuan (SPT) Masa dengan benar sesuai dengan ketentuan perpajakan yang berlaku. Dan untuk tahun pajak 2014-2015 (sesudah $1 \%$ ) saat penyetoran pajak $1 \%$ setiap bulan sudah langsung dianggap mengisi SPT. Akhirnya, wajib pajak juga wajib melaporkan Surat Pemberitahuan (SPT) Masa (PPh 21/26, 23, 4(2), 25) paling lambat tanggal 20 bulan berikutnya setelah masa pajak setiap bulannya. Dan untuk tahun pajak 2014-2015 (sesudah 1\%) saat penyetoran pajak $1 \%$ setiap bulan sudah langsung dianggap melaporkan SPT.

Dalam hal SPT Tahunan, wajib pajak harus menyetorkan pajak penghasilan $(\mathrm{PPh})$ badan tahunan paling lambat tanggal 30 April setelah tahun pajak setiap tahunnya. Dan untuk tahun pajak 2014-2015 (sesudah 1\%) tidak perlu lagi menyetorkan pajak tahunannya, namun terakhir penyetoran paling lambat tanggal 15 bulan Januari tahun berikutnya (1\% dari peredaran bruto bulan Desember). Wajib pajak juga harus mengisi Surat Pemberitahuan (SPT) Tahunan PPh Badan sesuai dengan ketentuan perpajakan yang berlaku. (Dan untuk tahun pajak 2014-2015 (sesudah 1\%) melaporkan NIHIL, karena telah dibayar pada setiap bulannya $1 \%$ dari peredaran bruto). Surat Pemberitahuan (SPT) Tahunan PPh Badan harus disampaikan paling lambat 30 April setelah tahun pajak setiap tahunnya.

Selain kewajiban SPT Masa dan kewajiban SPT Tahunan, wajib pajak juga memiliki kewajiban lainnya, yaitu membuat pembukuan atas semua penghasilan dan biaya serta transaksi keuangan lainnya, dan untuk tahun pajak 2014-2015 (sesudah 1\%) minimal pencatatan atas penghasilan setiap bulannya serta melakukan pemotongan pajak dari pihak lain terkait dengan kegiatan usaha (misalnya PPh 21/26, 23, 4(2), 25). 


\subsection{Analisis Uji Instrumen Penelitian}

Hasil Uji validitas menunjukkan bahwa $r_{\text {hitung }}$ lebih besar dari $r_{\text {tabel }}(\mathbf{0 , 2 0 6 1})$, dan antara skor masing-masing butir dengan skor total (Pearson Correlation) menunjukkan korelasi yang positif dan tingkat signifikan pada level 0,01, maka dapat dikatakan Valid. Dan pada uji reliabilitas, konsistensi internal koefisien cronbach's alpha menunjukkan tidak ada koefisien yang kurang dari nilai batas minimal 0,60. Dimana nilai cronbach's alpha paling kecil $\mathbf{0 , 8 9 9}(>\mathbf{0 , 6 0})$, sedangkan yang lainnya 0,9 keatas (>0,90). Maka berarti bagian kuesioner yang berisi jawaban/indikator mengenai tingkat kepatuhan pajak penghasilan adalah reliabel. Hasil Uji Validitas dan Reliabilitas Kuesioner dapat dilihat dalam Tabel 4.1.

\subsection{Karakteristik Responden}

Penelitian ini menggunakan 100 (seratus) responden, terdapat 9 kuesioner yang outlier, karena Peredaran bruto (omset) dalam 3 tahun terakhir (2003, 2014, dan 2015) masing-masing lebih dari Rp. 4.800.000.000,- (4,8 miliar rupiah). Maka tidak available menjadi sampel dalam penelitian ini. Karakteristik dari 91 responden dalam penelitian ini dibagi menjadi 4 (empat) kategori, yang meliputi jenis kelamin, usia, pendidikan terakhir, dan jenis usaha.

Berdasarkan jenis kelamin dapat diketahui bahwa dari total 91 responden, responden yang berjenis kelamin Laki-laki sebanyak $47 \%$ responden dan yang berjenis kelamin perempuan sebanyak $53 \%$. Sedangkan berdasarkan usia didapatkan bahwa dari total 91 responden berada pada kelompok usia terbanyak yaitu dengan kategori $31-40$ tahun sebesar 33\%. Dan kelompok usia terkecil dengan kategori 41 - 50 tahun sebesar $19 \%$, sedangkan untuk yang lain berada pada persentase $21 \%$ dan $27 \%$.

Tingkat pendidikan terakhir responden terbanyak sebesar 39\% yaitu Strata 1 (S1). Hal ini dikarenakan bahwa lulusan S1 berpeluang untuk bekerja sebagai staf perpajakan maupun bagian akuntansi. Dan kemudian diikuti kategori SMA (sederajat) sebesar 37\%, Diploma 3 (D3) sebesar 18\%, Diploma 1 (D1) dan Pascasarjana memiliki jumlah frekuensi yang sama yaitu 3 orang atau $3 \%$ dari 91 responden.

Berdasarkan jenis usaha 91 responden yang paling banyak menjadi sampel memiliki jenis usaha Real Estat, Usaha Persewaan, dan Jasa Perusahaan sebesar 32\% (29 responden). Diikuti dengan jenis usaha Jasa Lainnya 24\%, yang tergabung dalam: Pengadaan, Advertising, Percetakan/Fotocopy, Konsultan, Jasa Pendidikan dan Cleaning Service. Kemudian urutan ketiga merupakan jenis usaha Perdagangan besar dan eceran: Reparasi mobil, Sepeda motor, serta barang-barang keperluan pribadi dan rumah tangga sebesar $20 \%$. 
Tabel 4.1. Hasil Uji Validitas dan Reliabilitas Kuesioner

\begin{tabular}{|c|c|c|c|c|}
\hline Jawaban/Indikator & $\begin{array}{c}\text { rhitung } \\
\text { (corrected item- } \\
\text { total correlation) }\end{array}$ & Kesimpulan & $\begin{array}{l}\text { Nilai } \\
\text { Cronbach } \\
\text { Alpha }\end{array}$ & Keterangan \\
\hline $\begin{array}{l}\text { Menyetorkan pajak bulanan (masa) paling } \\
\text { lambat tanggal } 10 \text { atau } 15 \text { bulan berikutnya } \\
\text { setelah akhir masa pajak setiap bulannya } \\
\text { (PPh 21/26, 23, } 4 \text { (2), 25). Dan untuk tahun } \\
\text { pajak 2014-2015 (sesudah } 1 \% \text { ) setiap } \\
\text { bulannya ditambah menyetor sebesar } 1 \% \\
\text { dari peredaran bruto. }\end{array}$ & $0,863-0,889$ & Valid & 0,972 & Reliabel \\
\hline $\begin{array}{l}\text { Mengisi Surat Pemberitahuan (SPT) Masa } \\
\text { dengan benar sesuai dengan ketentuan } \\
\text { perpajakan yang berlaku. Dan untuk tahun } \\
\text { pajak 2014-2015 (sesudah 1\%) saat } \\
\text { penyetoran pajak } 1 \% \text { setiap bulan sudah } \\
\text { langsung dianggap mengisi SPT. }\end{array}$ & $0,872-0,912$ & Valid & 0,960 & Reliabel \\
\hline $\begin{array}{l}\text { Melaporkan Surat Pemberitahuan (SPT) } \\
\text { Masa (PPh 21/26, 23, 4(2), 25) paling } \\
\text { lambat tanggal } 20 \text { bulan berikutnya setelah } \\
\text { masa pajak setiap bulannya. Dan untuk } \\
\text { tahun pajak 2014-2015 (sesudah } 1 \% \text { ) saat } \\
\text { penyetoran pajak } 1 \% \text { setiap bulan sudah } \\
\text { langsung dianggap melaporkan SPT. }\end{array}$ & $0,885-0,915$ & Valid & 0,959 & Reliabel \\
\hline $\begin{array}{l}\text { Menyetorkan pajak penghasilan (PPh) } \\
\text { badan tahunan paling lambat tanggal } 30 \\
\text { April setelah tahun pajak setiap tahunnya. } \\
\text { Dan untuk tahun pajak 2014-2015 (sesudah } \\
1 \% \text { ) tidak perlu lagi menyetorkan pajak } \\
\text { tahunannya, namun terakhir penyetoran } \\
\text { paling lambat tanggal } 15 \text { bulan Januari } \\
\text { tahun berikutnya ( } 1 \% \text { dari peredaran bruto } \\
\text { bulan Desember). }\end{array}$ & $\mathbf{0 , 7 9 3 - 0 , 8 1 7}$ & Valid & 0,920 & Reliabel \\
\hline $\begin{array}{l}\text { Mengisi Surat Pemberitahuan (SPT) } \\
\text { Tahunan PPh Badan sesuai dengan } \\
\text { ketentuan perpajakan yang berlaku. (Dan } \\
\text { untuk tahun pajak 2014-2015 (sesudah 1\%) } \\
\text { melaporkan NIHIL, karena telah dibayar } \\
\text { pada setiap bulannya 1\% dari peredaran } \\
\text { bruto). }\end{array}$ & $0,826-0,845$ & Valid & $\mathbf{0 , 8 9 9}$ & Reliabel \\
\hline $\begin{array}{l}\text { Melaporkan Surat Pemberitahuan (SPT) } \\
\text { Tahunan PPh Badan paling lambat } 30 \text { April } \\
\text { setelah tahun pajak setiap tahunnya. }\end{array}$ & $0,802-0,820$ & Valid & 0,950 & Reliabel \\
\hline $\begin{array}{l}\text { Membuat pembukuan atas semua } \\
\text { penghasilan dan biaya serta transaksi } \\
\text { keuangan lainnya, Dan untuk tahun pajak } \\
2014-2015 \text { (sesudah } 1 \% \text { ) minimal } \\
\text { pencatatan atas penghasilan setiap } \\
\text { bulannya. }\end{array}$ & $0,809-0,828$ & Valid & $\mathbf{0 , 9 2 7}$ & Reliabel \\
\hline $\begin{array}{l}\text { Melakukan pemotongan pajak dari pihak } \\
\text { lain terkait dengan kegiatan usaha } \\
\text { (misalnya } \mathrm{PPh} 21 / 26,23,4(2), 25) \text {. }\end{array}$ & $0,865-0,868$ & Valid & 0,976 & Reliabel \\
\hline
\end{tabular}


Berikutnya untuk Penyediaan Akomodasi dan Penyediaan Makan Minum dan jenis usaha Transportasi, Pergudangan dan Komunikasi memiliki jumlah frekuensi yang sama yaitu 6 responden atau 7\%. Begitu pula untuk responden dengan jenis usaha Industri Pengolahan dan Perantara Keuangan memiliki jumlah persentase yang sama yaitu $5 \%$.

\subsection{Tingkat Kepatuhan Wajib Pajak Badan Di KPP Pratama Pontianak Sebelum dan Sesudah Adanya Kebijakan Pajak 1\% untuk Pengusaha UMKM dengan Omset (Peredaran Bruto) Mulai 1 Hingga Maksimal Hingga Rp 4,8 Miliar Per Tahun Bagi Wajib Pajak Badan UMKM}

Dalam pembahasan ini akan dijelaskan mengenai kepatuhan Wajib Pajak sebelum dan sesudah adanya kebijakan pajak 1\% untuk pengusaha UMKM dengan omset (peredaran bruto) mulai 1 hingga maksimal hingga Rp 4,8 miliar per tahun bagi Wajib Pajak badan UMKM. Kepatuhan Wajib Pajak akan dilihat dari Kewajiban Masa, Kewajiban Tahunan dan Kewajiban Lainnya (yang dibatasi hanya pada kewajiban pembukuan dan pemotongan pajak pihak lain). Terdapat 8 (delapan) pernyataan/ indikator yang dapat digunakan untuk mengukur tingkat kepatuhan kewajiban pajak penghasilan UMKM. Kuesioner yang telah diisi responden kemudian diberi skor pada setiap jawaban pernyataan. Dari hasil penskoran itu kemudian ditentukan apakah tingkat kepatuhan kewajiban pajak penghasilan Wajib Pajak sebelum dan sesudah adanya kebijakan fasilitas pengurangan tarif tergolong dalam kategori "rendah" atau "tinggi" berdasarkan nilai statistik dari Tabel 4.2.

Tabel 4.2. Statistik Deskriptif Untuk Kepatuhan Pajak Sebelum dan Sesudah Kebijakan Pajak 1\% dari omset/bulan

\begin{tabular}{ccccc}
\hline & $\mathrm{N}$ & \multicolumn{2}{c}{ Mean } & Std. Deviation \\
\hline & Statistic & Statistic & Std. Error & Statistic \\
\hline TotalSebelum & 91 & 25.46 & .915 & 8.731 \\
TotalSesudah & 91 & 25.84 & .896 & 8.547 \\
Valid N (listwise) & 91 & & & \\
\hline
\end{tabular}

Tabel 4.2 menunjukkan bahwa nilai mean (nilai rata-rata) tingkat kepatuhan badan sebelum adanya kebijakan pajak $1 \%$ dari omset/bulan adalah 25,46, sedangkan sesudah adanya kebijakan pajak $1 \%$ dari omset/bulan nilai meannya adalah 25,84 . Maka tingkat kepatuhan pajak sebelum adanya kebijakan dikatakan "rendah" apabila nilainya lebih kecil dari nilai mean yaitu 25,46 (dibulatkan 25, karena dibawah 0,50). Sedangkan, skor yang nilainya lebih besar dari nilai mean yaitu 25, tergolong kepatuhan "tinggi".

Sementara, sesudah adanya kebijakan pajak $1 \%$ dari omset/bulan nilai meannya adalah 25,84. Maka tingkat kepatuhan pajak sesudah adanya kebijakan dikatakan 
"rendah" apabila nilainya lebih kecil dari nilai mean yaitu 25,84 (dibulatkan 26). Pembulatan ke atas ini dilakukan untuk memudahkan peneliti melakukan analisis (Siagian, 2000). Sedangkan, skor yang nilainya lebih besar dari nilai mean yaitu 26, tergolong kepatuhan "tinggi". Setelah dilakukan pengkategorian, maka akan didapat jumlah responden yang memiliki tingkat kepatuhan pajak sesuai dengan kategori "rendah" atau "tinggi" sebelum dan sesudah adanya kebijakan pajak $1 \%$ dari omset/bulan.

Tabel 4.3. Tingkat Kepatuhan Pajak Sebelum dan Sesudah Kebijakan Pajak 1\% dari Omset/bulan

\begin{tabular}{cclcc}
\hline \multicolumn{2}{c}{ Kategori } & & Frekuensi & Persentase (\%) \\
\hline Tingkat kepatuhan badan sebelum adanya & Rendah $(<25)$ & 46 & $51 \%$ \\
kebijakan pajak 1\% dari omset/bulan & Tinggi $(>25)$ & 45 & $49 \%$ \\
\hline Total & & $\mathbf{9 1}$ & $\mathbf{1 0 0 \%}$ \\
\hline Tingkat kepatuhan badan sesudah adanya & Rendah $(<26)$ & 44 & $48 \%$ \\
kebijakan pajak 1\% dari omset/bulan & Tinggi $(>26)$ & 47 & $52 \%$ \\
\hline Total & & $\mathbf{9 1}$ & $\mathbf{1 0 0 \%}$ \\
\hline
\end{tabular}

Tabel 4.3 menunjukkan bahwa tingkat kepatuhan Wajib Pajak badan di KPP Pratama Pontianak sebelum dan sesudah adanya kebijakan pajak $1 \%$ dari omset/bulan mengalami peningkatan walaupun sedikit. Dari total 91 responden tingkat kepatuhan pajak sebelum adanya kebijakan pajak $1 \%$ dari omset/bulan sebesar $51 \%$ memiliki tingkat kepatuhan pajak yang "rendah". Sedangkan yang memiliki tingkat kepatuhan pajak yang "tinggi" lebih kecil yaitu 49\%. Sementara, sesudah adanya kebijakan pajak $1 \%$ dari omset/bulan, 52\% Wajib Pajak badan UMKM memiliki tingkat kepatuhan pajak yang "tinggi", sedangkan $48 \%$ lagi tingkat kepatuhannya masih "rendah".

Peningkatan kepatuhan pajak sesudah adanya kebijakan pajak $1 \%$ dari omset/bulan menunjukkan bahwa perubahan pembayaran perbulan dengan tarif final $1 \%$ dari omset kepada Wajib Pajak badan sektor UMKM dapat mendorong kepatuhan Wajib Pajak walaupun tidak besar. Hal ini seperti penelitian yang dilakukan Salamun dalam Vebrina (2012) yang menyatakan bahwa ada empat hal yang dapat mempengaruhi kepatuhan Wajib Pajak dalam memenuhi kewajiban perpajakannya, antara lain yaitu tarif pajak. Berikut ini akan disajikan secara terperinci frekuensi/persentase jawaban responden setiap item pernyataan yang ada dalam kuesioner dalam bentuk grafik/diagram.

\subsection{Kewajiban Surat Pemberitahuan (SPT) Masa}

Kewajiban masa atau bulanan Wajib Pajak meliputi, penyetoran pajak bulanan, pengisian SPT Masa, dan Pelaporan SPT Masa. Hasil jawaban responden untuk masingmasing indikator ditampilkan dalam Gambar 1. Sebelum diberlakukan $1 \%$ dari Peredaran Bruto Setiap Bulan (2012-2013) dari total 91 responden terdapat 23\% 
responden yang "Tidak Pernah" menyetorkan pajak bulanan (masa) tepat waktu setiap bulannya, 24\% yang "Kadang-kadang" menyetorkan pajak bulanan (masa) tepat waktu setiap bulannya, 9\% responden yang "Cukup Sering" menyetorkan pajak bulanan (masa) tepat waktu setiap bulannya, 24\% yang "Sering" menyetorkan pajak bulanan (masa) tepat waktu setiap bulannya, dan $20 \%$ yang "Selalu" menyetorkan pajak bulanan (masa) paling lambat tanggal 10 atau 15 berikutnya setelah akhir masa pajak setiap bulannya.

Sedangkan jika dibandingkan dengan Sesudah penetapan kebijakan terbaru Peraturan Pemerintah Nomor 46 Tahun 2013 yaitu 1\% dari Peredaran Bruto Setiap Bulan (2014-2015) untuk pengusaha UKM dengan omset (peredaran bruto) mulai 1 hingga maksimal hingga Rp 4,8 miliar per tahun terdapat sedikit peningkatan kepatuhan. Yaitu penurunan responden yang "Tidak Pernah" menyetorkan pajak bulanan (masa) tepat waktu setiap bulannya menjadi 21\%, dan 22\% yang "Kadang-kadang" menyetorkan pajak bulanan (masa) tepat waktu setiap bulannya. Dan peningkatan persentase untuk responden yang "Cukup Sering", "Sering" dan "Selalu" menyetorkan pajak bulanan (masa) tepat waktu setiap bulannya masing-masing menjadi 10\%, 25\% dan $22 \%$.

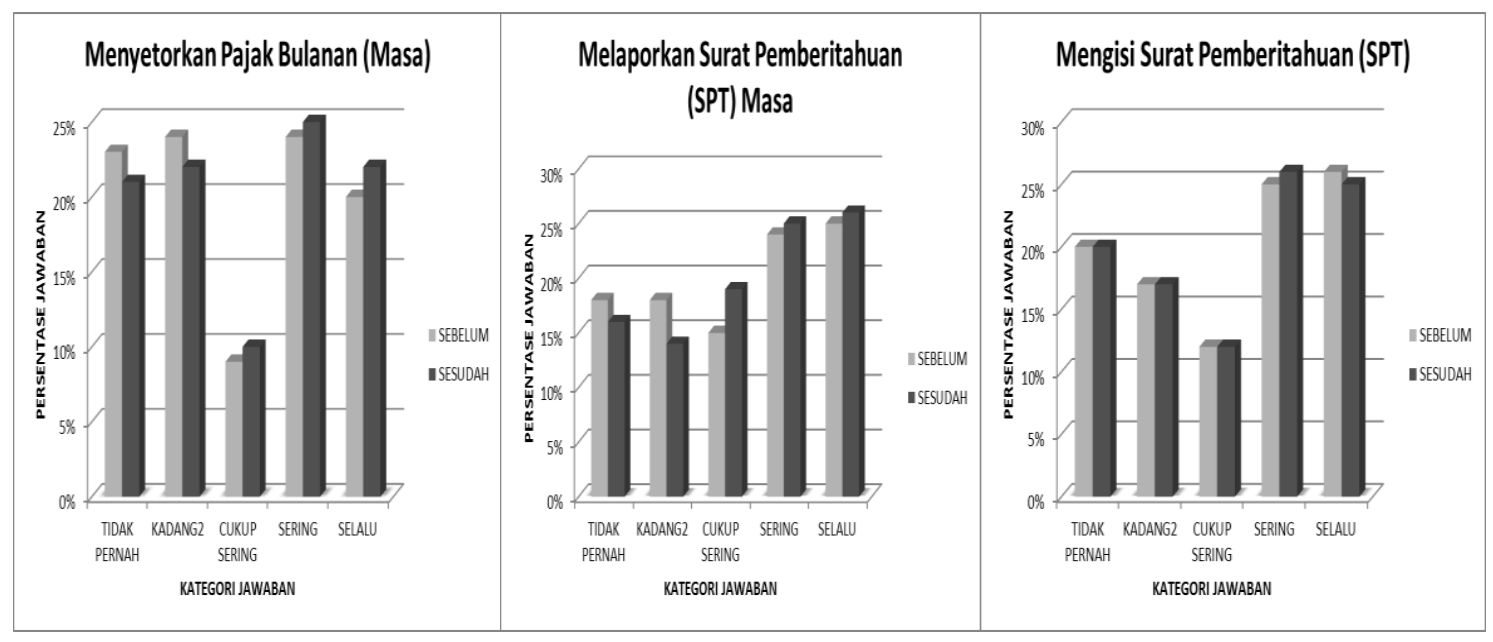

\section{Gambar 1. Diagram Kepatuhan Kewajiban Surat Pemberitahuan (SPT) Masa}

Sebelum diberlakukan 1\% dari Peredaran Bruto Setiap Bulan (2012-2013) persentase kepatuhan responden yang "Tidak Pernah", "Kadang-kadang", "Cukup Sering", "Sering" dan "Selalu" mengisi SPT Masa sesuai dengan ketentuan perpajakan yang berlaku secara berurutan masing-masing adalah 20\%, 17\%, 12\%, 25\%, dan $26 \%$. Nilai ini hampir sama dengan hasil jawaban responden untuk kondisi sesudah diberlakukan 1\% dari Peredaran Bruto Setiap Bulan (2014-2015), kecuali untuk persentase pada kategori "Sering" dan "Selalu".

Untuk kategori "Sering" dan "Selalu" terdapat perbedaan yang menunjukkan pertukaran frekuensi dan persentase yaitu untuk Sebelum diberlakukan $1 \%$ dari 
Peredaran Bruto Setiap Bulan (2012-2013) jawaban "Sering" sebanyak 23 (25\%) dan "Selalu" sebanyak 24 (26\%). Sedangkan untuk sesudah diberlakukan 1\% dari Peredaran Bruto Setiap Bulan (2014-2015) jawaban "Sering" menjadi bertambah sebesar 24 (26\%) dan "Selalu" berkurang menjadi 23 (25\%).Sebelum diberlakukan 1\% dari Peredaran Bruto Setiap Bulan (2012-2013) dari total 91 responden terdapat 18\% untuk responden yang "Tidak Pernah" dan "Kadang-kadang", 15\% responden yang "Cukup Sering", 24\% yang "Sering", dan 25\% yang "Selalu" melaporkan Surat Pemberitahuan (SPT) Masa (PPh 21, 23, 4(2), dan 25) paling lambat tanggal 20 bulan berikutnya setelah masa pajak setiap bulannya. Sedangkan jika dibandingkan dengan Sesudah penetapan kebijakan terbaru Peraturan Pemerintah Nomor 46 Tahun 2013 yaitu 1\% dari Peredaran Bruto Setiap Bulan (2014-2015) untuk pengusaha UKM dengan omset (peredaran bruto) mulai 1 hingga maksimal hingga Rp 4,8 miliar per tahun terdapat sedikit peningkatan kepatuhan. Yaitu penurunan responden yang "Tidak Pernah" melaporkan Surat Pemberitahuan (SPT) Masa ( $\mathrm{PPh} \mathrm{21,} \mathrm{23,} \mathrm{4(2),} \mathrm{dan} \mathrm{25)} \mathrm{paling} \mathrm{lambat} \mathrm{tanggal} 20$ bulan berikutnya setelah masa pajak setiap bulannya menjadi $16 \%$, dan $14 \%$ yang "Kadangkadang". Dan peningkatan persentase untuk responden yang "Cukup Sering", "Sering" dan "Selalu" menyetorkan pajak bulanan (masa) tepat waktu setiap bulannya masingmasing menjadi $19 \%, 25 \%$ dan $26 \%$.

\subsection{Kewajiban Surat Pemberitahuan (SPT) Tahunan}

Kewajiban tahunan Wajib Pajak meliputi; penyetoran pajak tahunan, pengisian SPT Tahunan, dan pelaporan SPT Tahunan. Hasil jawaban responden untuk masingmasing indikator ditampilkan dalam grafik/diagram sebagai berikut:



Gambar 2. Diagram Kepatuhan Kewajiban Surat Pemberitahuan (SPT) Tahunan 
Dari Gambar 2 dapat dipaparkan setiap jawaban indikator pernyataan berkenaan dengan kepatuhan kewajiban surat pemberitahuan (SPT) tahunan. Sebelum diberlakukan 1\% dari Peredaran Bruto Setiap Bulan (2012-2013) dari total 91 responden terdapat 16\% responden yang "Tidak Pernah" taat di dalam menyetorkan pajak penghasilan $(\mathrm{PPh})$ badan sebelum tanggal 30 April setiap tahunnya. 18\% responden yang "Kadangkadang", 8\% responden yang "Cukup Sering" dan 35\% yang "Sering" menyetorkan pajak penghasilan $(\mathrm{PPh})$ badan tepat waktu setiap tahunnya. Sisanya 23\% yang "Selalu" tepat waktu menyetorkan pajak penghasilan ( $\mathrm{PPh}$ ) badan sebelum tanggal 30 April setiap tahunnya.

Sedangkan jika dibandingkan dengan Sesudah penetapan kebijakan terbaru Peraturan Pemerintah Nomor 46 Tahun 2013 yaitu 1\% dari Peredaran Bruto Setiap Bulan (2014-2015) untuk pengusaha UKM dengan omset (peredaran bruto) mulai 1 hingga maksimal hingga Rp 4,8 miliar per tahun terdapat sedikit peningkatan kepatuhan. Yaitu peningkatan jumlah responden dan persentase untuk responden yang "Selalu" menyetorkan pajak penghasilan (PPh) badan sebelum tanggal 30 April setiap tahunnya dari 21 menjadi 22 responden dengan persentase $23 \%$ menjadi $24 \%$.

Sebelum diberlakukan 1\% dari Peredaran Bruto Setiap Bulan (2012-2013) persentase kepatuhan responden "Selalu" mengisi SPT Tahunan sesuai dengan ketentuan perpajakan yang berlaku 22\%, 24\% yang "Sering", dan 22\% yang "Cukup Sering" sedangkan yang "Kadang-kadang" dan "Tidak Pernah" berjumlah 13 dan 16 dengan masing-masing persentase $14 \%$ dan $18 \%$.

Sesudah diberlakukan 1\% dari Peredaran Bruto Setiap Bulan (2014-2015) jawaban "Cukup Sering" dan "Selalu" menjadi bertambah sebesar 24 (26\%) dari sebelumnya berjumlah 20 (22\%). Selain itu juga terjadi penurunan yang signifikan pada jumlah responden yang menjawab dengan kategori "Kadang-kadang" yaitu dari berjumlah $13(14 \%)$ responden menjadi berjumlah $6(7 \%)$ responden saja. Hal ini menunjukkan bahwa Penetapan Peraturan Pemerintah Nomor 46 Tahun 2013 yaitu 1\% dari Peredaran Bruto Setiap Bulan menyebabkan peningkatan kepatuhan Wajib Pajak Badan (UMKM) yang mengisi SPT Tahunan sesuai dengan ketentuan perpajakan yang berlaku.

Dari Gambar 2 diketahui bahwa Sebelum diberlakukan 1\% dari Peredaran Bruto Setiap Bulan (2012-2013) dari total 91 responden terdapat 5\% untuk responden yang "Tidak Pernah" dan 12\% untuk responden yang "Kadang-kadang", 19\% responden yang "Cukup Sering", 30\% yang "Sering", dan 34\% yang "Selalu" melaporkan Surat Pemberitahuan (SPT) Tahunan sebelum tanggal jatuh tempo. Sedangkan Sesudah penetapan kebijakan terbaru Peraturan Pemerintah Nomor 46 Tahun 2013 yaitu 1\% dari Peredaran Bruto Setiap Bulan (2014-2015) untuk pengusaha UKM dengan omset (peredaran bruto) mulai 1 hingga maksimal hingga $\mathrm{Rp} 4,8$ miliar per tahun terdapat perbedaan 3 poin untuk penurunan jawaban responden "Kadang-kadang" dan peningkatan jawaban responden "Selalu". Hal ini menunjukkan bahwa Penetapan 
Peraturan Pemerintah Nomor 46 Tahun 2013 yaitu 1\% dari Peredaran Bruto Setiap Bulan menyebabkan peningkatan kepatuhan Wajib Pajak Badan (UMKM) yang mengisi SPT Tahunan sesuai dengan ketentuan perpajakan yang berlaku.

\subsection{Kewajiban Lainnya}

Hasil jawaban responden untuk indikator membuat pembukuan dan melakukan pemotongan pajak dari pihak lain sebagai pemenuhan kewajiban lainnya wajib pajak ditampilkan dalam Gambar 3.

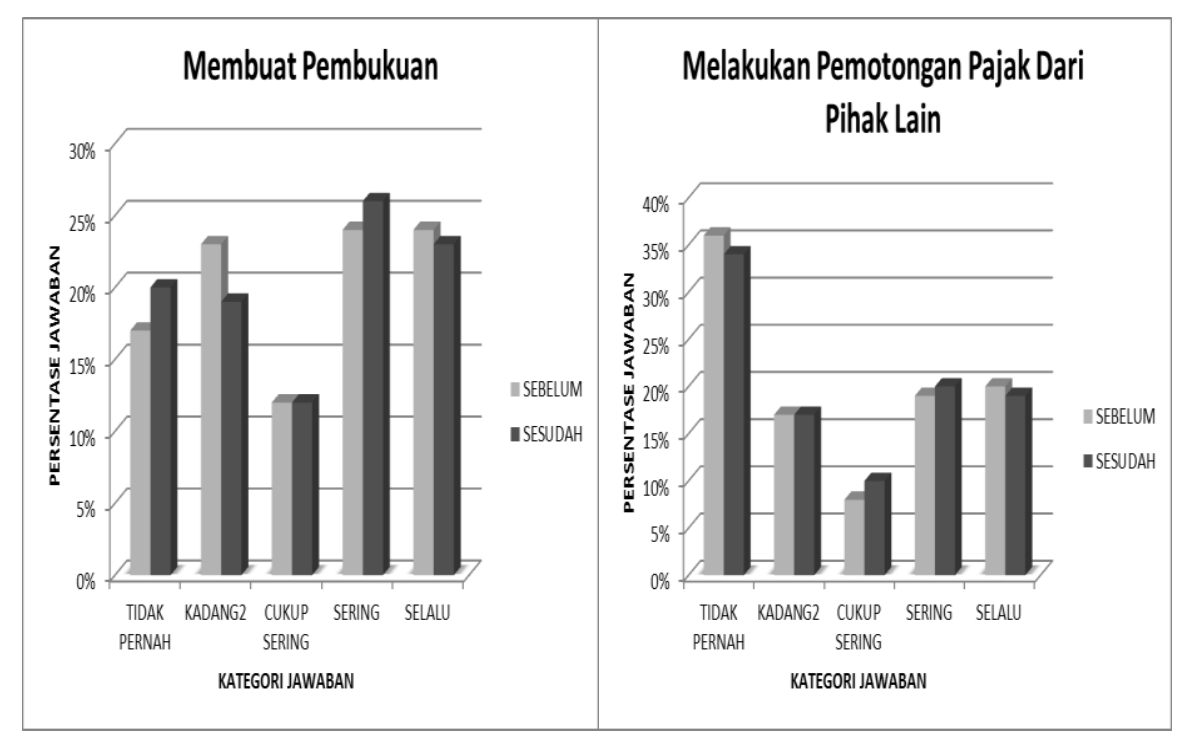

Gambar 3. Diagram Kepatuhan Kewajiban Lainnya

Berdasarkan Gambar 3, rincian jawaban Sebelum diberlakukan 1\% dari Peredaran Bruto Setiap Bulan dan Sesudah diberlakukan 1\% dari Peredaran Bruto Setiap Bulan. Sebelum diberlakukan 1\% dari Peredaran Bruto Setiap Bulan (2012-2013) dari total 91 responden terdapat 17\% responden yang "Tidak Pernah", 23\% responden yang "Kadang-kadang", 12\% responden yang "Cukup Sering" dan $24 \%$ untuk yang "Sering" dan "Selalu" melakukan pembukuan atas semua penghasilan dan biaya serta transaksi keuangan lainnya. Sedangkan jika dibandingkan dengan Sesudah penetapan kebijakan terbaru Peraturan Pemerintah Nomor 46 Tahun 2013 yaitu 1\% dari Peredaran Bruto Setiap Bulan (2014-2015) untuk pengusaha UKM dengan omset (peredaran bruto) mulai 1 hingga maksimal hingga Rp 4,8 miliar per tahun terdapat beberapa perubahan, terjadi inkonsistensi, misalnya pada kategori jawaban "Tidak Pernah" dan "Kadang-kadang" yaitu pada kategori jawaban "Tidak Pernah" mengalami peningkatan 3 poin dari 15 menjadi 18 (20\%) yang berarti penurunan kepatuhan pajak Wajib Pajak, kontras dengan kategori jawaban "Kadang-kadang" mengalami penurunan hingga 4 poin dari 21 menjadi 17 (19\%), dan berarti peningkatan kepatuhan pajak Wajib Pajak. 
Hal ini juga terjadi pada kategori jawaban "Sering" dan "Selalu" yaitu pada kategori jawaban "Sering" mengalami peningkatan 2 poin dari 22 menjadi 24 (26\%) yang berarti peningkatan kepatuhan pajak Wajib Pajak, sebaliknya dengan kategori jawaban "Selalu" mengalami penurunan hingga 1 poin dari 22 menjadi 21 (23\%), dan berarti penurunan kepatuhan pajak Wajib Pajak. Hasil tela'ah peneliti, kemungkinan karena tuntutan dilakukannya pembukuan sederhana setiap bulannya untuk memenuhi kewajiban pajak, ada Wajib Pajak Badan yang menyanggupi, namun terdapat juga Wajib Pajak Badan yang tidak menyanggupi atau belum melakukan pembukuan. Sedangkan pada kategori jawaban "Cukup Sering” antara sebelum dan sesudah penetapan kebijakan terbaru Peraturan Pemerintah Nomor 46 Tahun 2013 yaitu 1\% dari Peredaran Bruto Setiap Bulan (2014-2015) untuk pengusaha UKM dengan omset (peredaran bruto) mulai 1 hingga maksimal hingga Rp 4,8 miliar per tahun mempunyai jumlah Frekuensi dan Persentase yang sama 11 dan $12 \%$.

Dari Gambar 3 diketahui bahwa baik Sebelum maupun Sesudah diberlakukan 1\% dari Peredaran Bruto Setiap Bulan persentase kepatuhan responden yang "Tidak Pernah" melakukan pemotongan atau pemungutan pajak dari pihak lain merupakan kategori jawaban yang paling banyak diisi responden yaitu sebesar 36\% untuk sebelum dan $34 \%$ sesudah. Namun paling tidak terjadi pengurangan/penurunan jumlah sesudah diberlakukan 1\% dari Peredaran Bruto Setiap Bulan yang berarti terjadi peningkatan kepatuhan Wajib Pajak. Hal ini disadari peneliti, karena di saat berkomunikasi singkat dengan responden, ditarik kesimpulan banyaknya ketidak-tahuan Wajib Pajak atas kewajiban tersebut.

Namun untuk kategori jawaban "Kadang-kadang" memiliki poin frekuensi yang sama yaitu 16 dengan persentase 17\%. Sedangkan untuk kategori jawaban "Cukup Sering" terjadi peningkatan jumlah sesudah diberlakukan $1 \%$ dari Peredaran Bruto dari sebelum diberlakukannya sejumlah 7 menjadi 9 atau dari $8 \%$ menjdi $10 \%$. Untuk kategori "Sering" dan "Selalu" terdapat perbedaan yang menunjukkan pertukaran frekuensi dan persentase yaitu untuk Sebelum diberlakukan 1\% dari Peredaran Bruto Setiap Bulan (2012-2013) jawaban "Sering" sebanyak 17 (19\%) dan "Selalu" sebanyak 18 (20\%). Sedangkan untuk sesudah diberlakukan 1\% dari Peredaran Bruto Setiap Bulan (2014-2015) jawaban "Sering" menjadi bertambah sebesar 18 (20\%) dan "Selalu" berkurang menjadi 17 (19\%). Hal ini dapat didukung dengan penjelasan pada paragraf sebelumnya bahwa hal ini disebabkan ketidak-tahuan Wajib Pajak atas kewajiban melakukan pemotongan atau pemungutan pajak dari pihak lain.

\subsection{Upaya-Upaya yang Dilakukan Fiskus dalam Meningkatkan Kepatuhan Wajib Pajak Badan dalam Hal Menyampaikan Kewajiban Perpajakannya}

Hasil wawancara dengan fiskus yang terlibat langsung dengan kegiatan Pembayaran dan Pelaporan Kewajiban Perpajakan maka didapat beberapa upaya yang 
dilakukan untuk meningkatkan kepatuhan Wajib Pajak, antara lain sebagai berikut. Pertama, melakukan sosialisasi hak dan kewajiban Wajib Pajak. Kedua, khusus Wajib Pajak yang baru terdaftar, saat pengambilan kartu NPWP akan dilakukan briefing/asistensi oleh petugas dengan menyampaikan segala hak dan kwajiban Wajib Pajak serta sanksi yang akan diberikan jika tidak melaksanakan kewajiban sesuai peraturan perpajakan. Ketiga, adanya tarif pajak yang sederhana, untuk Wajib Pajak yang memiliki omset dibawah 4,8 Miliar, diberikan satu tarif final yaitu $1 \%$ dari omset. Keempat, dibuat cara pembayaran yang mudah, untuk Wajib Pajak yang memiliki omset dibawah 4,8 Miliar pembayaran 1\% dari omset tersebut bisa via mesin ATM di seluruh bank persepsi, pembayaran pajak ada di menu mesin ATM. Kelima, pelaporan SPT Masa yang mudah, Seperti diketahui untuk Wajib Pajak yang sudah melakukan pembayaran pajak bulanan maka sudah tidak diwajibkan untuk malakukan pelaporan lagi di KPP Pratama. Keenam, menaikkan batasan peredaran usaha Pengusaha Kecil dari 600 juta menjadi 4,8 Miliar, sehingga Wajib Pajak yang memiliki omset dibawah 4,8 Miliar tidak perlu dikukuhkan sebagai Pengusaha Kena Pajak (PKP) sehingga tidak perlu melaporkan SPT Masa PPN. Ketujuh, pelaporan SPT Tahunan yang mudah, Wajib Pajak yang memiliki omset dibawah 4,8 Miliar tidak menghitung kembali pajak yang terutang yang sudah dibayarkan tiap bulan, sehingga cukup melaporkan pada kolom final. Yang terakhir adalah penegakan hukum.

\section{KESIMPULAN}

Dari hasil analisa data, terdapat sedikit peningkatan kepatuhan wajib pajak badan di KPP Pratama Pontianak sesudah adanya kebijakan pajak $1 \%$ perbulan dari omset (peredaran bruto), jika dibandingkan dengan sebelum adanya kebijakan. Hal ini ditunjukkan, dari total 91 responden tingkat kepatuhan pajak sebelum adanya kebijakan pajak $1 \%$ dari omset/bulan sebesar $51 \%$ memiliki tingkat kepatuhan pajak yang "rendah". Sedangkan, sesudah adanya kebijakan pajak 1\% dari omset/bulan, 52\% Wajib Pajak badan UMKM memiliki tingkat kepatuhan pajak yang "tinggi", sedangkan 48\% lagi tingkat kepatuhannya masih "rendah". Dalam hal ketiga kewajiban wajib pajak yang dibahas dalam penelitian ini, terlihat adanya penurunan responden yang "Tidak Pernah" dan peningkatan persentase untuk responden yang "Cukup Sering", "Sering" dan "Selalu" menyetorkan pajak bulanan (masa) tepat waktu setiap bulannya. Sedangkan, untuk kewajiban SPT Tahunan, terdapat perbedaan 3 poin untuk penurunan jawaban responden "Kadang-kadang" dan peningkatan jawaban responden "Selalu". Akhirnya, terjadi pengurangan/penurunan jawaban "Tidak Pernah" melakukan pemotongan atau pemungutan pajak dari pihak lain yang merupakan kewajiban lainnya bagi wajib pajak.

Upaya yang dilakukan untuk meningkatkan kepatuhan Wajib Pajak, antara lain sebagai berikut; Melakukan sosialisasi hak dan kewajiban Wajib Pajak, Khusus Wajib Pajak yang baru terdaftar, dilakukan briefing/asistensi, Adanya tarif pajak yang 
sederhana, Dibuat cara pembayaran yang mudah, Pelaporan SPT Masa yang mudah, Menaikkan batasan peredaran usaha Pengusaha Kecil dari 600 juta menjadi 4,8 Miliar, Pelaporan SPT Tahunan yang mudah, dan terakhir Penegakan hukum.

\section{DAFTAR PUSTAKA}

Devano, S. \& Rahayu, S. K. (2006). Perpajakan: Konsep, Teori dan isu. Jakarta: Kencana.

Direktorat Jenderal Pajak. (2015). Realisasi Penerimaan Pajak per 30 April 2015. Diakses dari http://www.pajak.go.id/content/realisasi-penerimaan-pajak-30-april2015.

Kementerian Koperasi \& UKM. (2013). Statistik Usaha Kecil, Mikro dan Menengah, Diakses dari http://www.depkop.go.id/phocadownload/data_statistik/statistik_ UKM/narasi_statistik_umkm\%202010-2011.pdf.

Keputusan Menteri Keuangan No.544/KMK.04/2000 tentang Kriteria Wajib Pajak Yang Dapat Diberikan Pengembalian Pendahuluan Kelebihan Pembayaran Pajak Menteri Keungan Republik Indonesia.

Mardiasmo. (2011). Perpajakan. Yogyakarta: Andi.

Peraturan Pemerintah Nomor 46 Tahun 2013 tentang tentang Pajak Penghasilan atas usaha dengan Penghasilan Bruto dan Kriteria Tertentu.

Peraturan Menteri Keuangan 107/011/2013 tentang Tentang Tata Cara Penghitungan, Penyetoran, dan Pelaporan Pajak Penghasilan Atas Penghasilan Dari Usaha Yang Diterima Atau Diperoleh Wajib Pajak Yang Memiliki Peredaran Bruto Tertentu.

Prasetyo, B. \& Jannah, L. M. (2015). Metodologi Penelitian Kuantitatif : Teori dan Aplikasi. Jakarta: Rajagrafindo Persada.

Rahayu, S. K. (2010). Perpajakan Indonesia (Konsep dan Aspek Sosial). Yogyakarta: Graha Ilmu.

Siagian, D. \& Sugiarto. (2000). Metode Statistika Untuk Bisnis dan Ekonomi. Jakarta: PT Gramedia Pustaka Utama.

Soebakir, M., Hon, D. B. H. \& Saragih, P. (1996). Petunjuk Praktis Perpajakan, Jakarta: Berita Pajak.

Vebrina, S. (2012). Tingkat Kepatuhan Wajib Pajak Badan Usaha Mikro Kecil dan Menengah Pasca Kebijakan Fasilitas Pengurang Tarif PPh di KPP Pratama Jakarta Kebayoran Lama (Skripsi yang dipublikasikan). Fakultas Ilmu Sosial dan Ilmu Politik Program Studi Administrasi Fiskal, Universitas Indonesia.

Undang-undang Nomor 28 Tahun 2007 tentang Ketentuan Umum Dan Tata Cara Perpajakan (KUP). 
Waluyo. (2013). Perpajakan Indonesia (Ed. 11). Jakarta: Salemba Empat. 